\title{
CZESŁAWA ZNAMIEROWSKIEGO KONCEPCJA WŁADZY JAKO ŁĄCZNEGO STANOWIENIA NORM
}

I. Władza polega między innymi na stanowieniu norm. Twierdzenie to, którego rozwinięcie jest celem niniejszego artykułu, można przyjąć za punkt wyjścia. Nie wyłącza ono innych sposobów ujmowania problematyki władzy w ramach różnych nauk. Pozwala jednak wydzielić te, które mogą być użyteczne w rozważaniach prawniczych. Jeśli norma jest podstawowym dla prawnika pojęciem w rozważaniach o prawie, to powinna też być użyteczna w refleksji nad władzą. Także filozofowie, którym nieobca jest refleksja nad prawem, konstatuja, że: ,władza prawa jest z definicji normatywna” ${ }^{1}$.

Problem relacji między stanowieniem norm a władzą pojawia się w polskiej teorii prawa, dysponującej pojęciem ,stanowienie norm” - rozumianym jako czynność konwencjonalna upoważnionego podmiotu, przez którą podmiot ów żąda posłuchu dla stanowionych przez siebie norm ${ }^{2}$. Takie rozumienie stanowienia norm nie wyjaśnia, na czym polega władza. Na przykład Zygmunt Ziembiński odnotowuje jedynie trudność związaną z uzasadnieniem tetycznym i wyjaśnia, na czym polega „dysponowanie władzą”. Władza, o jakiej pisze Ziembiński, odnosi się raczej do tego, co Znamierowski opisuje jako sytuację, w której ktoś ma władzę ,,pod danym względem” i ,co się tyczy wykonania czynu c"

Teoria prawa potrzebuje refleksji nad władzą. Po pierwsze dlatego, że władza jest pojęciem prawnym ${ }^{5}$. Po drugie, ponieważ pojęcie to występuje

${ }^{1}$ T. Buksiński, Prawo a wtadza polityczna, Uniwersytet im. Adama Mickiewicza w Poznaniu, Wydawnictwo Naukowe Instytutu Filozofii, Poznań 2009, s. 200.

${ }^{2}$ Por. m.in. Z. Ziembiński, Problemy podstawowe prawoznawstwa, PWN, Warszawa 1980, s. 418.

3 „Definicja tetycznego uzasadnienia normy zawiera [...] swoiste ignotum, w postaci odwołania się do pojęcia posiadania władzy. Jest to już pojęcie z kategorii pojęć socjologicznych. Najogólniej chyba można byłoby powiedzieć, że jakiś podmiot dysponuje władzą w stosunku do innego podmiotu, jeżeli zachodzi odpowiednio wysokie prawdopodobieństwo, że określone nakazy przezeń sformułowane spotkają się z posłuchem adresata normy, właśnie ze względu na fakt ustanowienia tych norm przez tego normodawcę" (ibidem, s. 144).

${ }^{4}$ C. Znamierowski, Układ prawny i norma prawna, wyd. 2, Górski i Tetzlaw, Poznań 1934, s. 67. Trudno oczywiście krytykować tu Ziembińskiego - wszak nie o władzy pisał. Jednak nawet jeśli pojęcia władzy nie potrzeba do zrozumienia stanowienia (choć moim zdaniem potrzeba, a nauka powinna wyjaśniać podobne ignota), to być może pojęcie stanowienia pozwoli nam lepiej zrozumieć, czym jest władza. Nie chodzi przy tym o jakąś substancjalną definicję władzy - takie zresztą istnieją - lecz o ujęcie, które korespondowałoby z potrzebami i doświadczeniem wspólnoty prawniczej.

${ }^{5} \mathrm{Nie}$ ulega to wątpliwości szczególnie dzisiaj, gdy prawo konstytucyjne osiagnęło pośród gałęzi prawa pozycję, jakiej dotychczas nie zajmowało. Dość wskazać, że słowo „,władza” pojawia się w obowiązującej Konstytucji RP aż 56 razy, a pojęcie ,norma” tylko raz, i to w dodatku w pomijanym w rozważaniach teoretycznoprawnych wyrażeniu: „,normy czasu pracy” (art. 66). 
w rozważaniach z zakresu nauk społecznych i filozofii, z którymi teoria prawa może się integrować. Po trzecie, pojęcie władzy rzuca światło na pojęcie normy. Po czwarte, niebezdyskusyjnie, refleksja nad władzą służy przywracaniu ciagłości refleksji nad prawem, przerwanej przez motywowane politycznie i ideologicznie uprawianie w przeszłości „teorii państwa i prawa”. W związku z wymienionymi powodami, w niniejszych rozważaniach będę inspirował się ustaleniami Czesława Znamierowskiego ${ }^{6}$, podejmując próbę ich interpretacji i zastosowania.

By wyjaśnić związek między stanowieniem a władzą, trzon rozważań koncentrować się będzie na stanowieniu łącznym. Zaproponowane zostaną trzy interpretacje tego, czym sa pojawiające się w wyniku takiego stanowieniaw ujęciu Znamierowskiego - normy generalnego zakazu jako normy nieindywidualne. Interpretacje te posłużą uwypukleniu właściwości stanowienia łącznego oraz wyjaśnią, dlaczego stanowienie łączne ułatwia zrozumienie władzy. $\mathrm{Na}$ zakończenie przedstawione zostanie ujęcie władzy jako stosunku między partnerami stanowienia łącznego z krótką refleksją na temat jego przydatności.

II. Normy mają w zasadzie źródło obowiązywania w stanowieniu ${ }^{7}$. Znamierowski wyróżnia trzy rodzaje stanowienia: rozkaz, stanowienie oparte na posłuchu $^{8}$ i stanowienie łączne. Poszczególne postacie stanowienia norm ujawniaja, że sens stosunku władzy sprowadza się do powstania norm, a przynajmniej jednej normy merytorycznej ${ }^{9}$.

Rozkaz, który dla Znamierowskiego jest oznaką skutecznego stosunku władzy, to najprostsza postać stanowienia norm. Rozkaz powoduje zmianę stanu równowagi między władca, którego moc ulega zwiększeniu, a podlegającym władzy, którego zakres możliwych czynów doznaje umniejszenia. Charakterystyczna dla rozkazu jest faktyczna zależność rozkazobiorcy od rozkazodawcy, choć nawet w tym wypadku można dostrzec zależność odwrotną: ,[...] ten, kto wydaje rozkaz, wydaje go dlatego, że jest pod jakimś względem zależny od tego, kto ma wykonać czyn nakazany"10. Inną właściwością rozkazu jest brak udziału woli tego, dla kogo norma jest w ten sposób ustanawiana ${ }^{11}$. Anatomia stanowienia norm pozostaje $\mathrm{w}$ wypadku rozkazu nieodmiennie prosta: jeśli $\mathrm{B}$ pozostaje $\mathrm{w}$ mocy $\mathrm{A}^{12}$, to $\mathrm{A}$ może stanowić normy dla $\mathrm{B}$ i takie stanowienie jest władzą ${ }^{13}$.

${ }^{6}$ Myśl Znamierowskiego pozostaje ważnym źródłem inspiracji dla polskiej teorii prawa, czego świadectwem są m.in. prace S. Czepity i M. Smolaka.

7 Zob. C. Znamierowski, Prolegomena do nauki o państwie, Poznań 1947, s. 160.

${ }^{8}$ Zob. ibidem, s. 134. Wyróżnianie tego typu stanowienia nie wydaje się do końca uzasadnione i nie będzie w tym miejscu omawiane.

${ }^{9}$ Znamierowski mówi o normach merytorycznych bynajmniej nie dla odróżnienia ich od norm kompetencyjnych. W wypadku norm kompetencyjnych - jego zdaniem - różnica dotyczy jedynie rodzaju działań wyznaczonych przez normę. Jeśli norma wyznacza działanie polegające na stanowieniu, to jest międzyosobową normą kompetencyjną. Por. ibidem, s. 175.

${ }^{10}$ Zob. ibidem, s. 110.

11 Zob. C. Znamierowski, Uktad prawny..., s. 68.

${ }_{12}$ Pozostawanie w czyjejś mocy jest stanem faktycznym, nieutożsamialnym z podleganiem władzy.

13 Zob. C. Znamierowski, Prolegomena..., s. 100. 
III. Myśli, że stosunek władzy skutkujący ustanowieniem norm może wiązać się ze współdziałaniem między tym, kto ma władzę, a tym, kto władzy podlega, odpowiada koncepcja stanowienia łącznego, które polegać ma - może wbrew intuicjom związanym $\mathrm{z}$ tym określeniem - na ustanowieniu normy kompetencji normodawczej przez podmiot podległy władzy na rzecz władającego, z którym podległy „,chce rozstrzygnąć [...] sprawę łącznie” ${ }^{14}$.

To właśnie stanowienie łączne wprowadza do stanowienia norm zagadnienie kompetencji jako warunek konieczny. Oczywiście historycznie pierwszą normę kompetencyjną ustanawia się aktem indywidualnym: stanowienie łączne opierające się na normie kompetencyjnej ustanowionej $\mathrm{w}$ drodze stanowienia łącznego byłoby niemożliwe, ponieważ wymagałoby nieskończonej ilości uprzednich stanowień łącznych. Z kolei rozkaz nie musi być czynnością konwencjonalną: pozostaje aktem faktycznym, związanym z rzeczywistym położeniem podmiotu podległego. Osłabia to przydatność kategorii rozkazu do określania stosunku władzy ${ }^{15}$.

Stanowienie łączne przebiega według następującego schematu. Jeśli podmiot upoważniony w ramach stanowienia łącznego uczyni użytek z przyznanej mu kompetencji, to zaktualizuje się dla niego obowiązek powstrzymania się od wszelkich działań (w tym normodawczych), które uniemożliwiłyby adresatowi realizację normy, będącej efektem uczynienia użytku z normy kompetencji normodawczej. W tej sytuacji na podmiocie posiadającym władzę zaczynaja spoczywać ,,wszystkie obowiązki, jakie mocą logicznej konieczności narzuca na stanowiącego daną normę sprzężona $\mathrm{z}$ nią norma generalnego zakazu" ${ }^{16}$, ponieważ nie powinien on czynić nic, co uniemożliwiłoby realizowanie ustanowionej przezeń normy merytorycznej. Podobna norma generalnego zakazu ma także obowiązywać podmiot podległy kompetencji normodawczej. Łączne stanowienie przejawia się też w powstałym ,układzie” norm oraz w tym, że stanowienie takie jest zawisłe, to znaczy zależy od wiedzy stanowiącego współnormodawcy o sytuacji drugiego podmiotu ${ }^{17}$. Modelowa sytuacja, w której celem było ustanowienie jednej normy merytorycznej indywidualnej (konkretnej albo abstrakcyjnej), prowadzi zatem - zgodnie z wywodem Znamierowskiego - do powstania zespołu norm powiązanych funkcjonalnie.

IV. Na podstawie rozważań rozproszonych w pracach Znamierowskiego można dowodzić, że nie jest możliwe ustanowienie jednej i tylko jednej normy merytorycznej. Pierwsza strategia dowodzenia opiera się na pojęciu normy izolowanej ${ }^{18}$ i nie ma takiej mocy wyjaśniającej jak druga strategia - oparta na stanowieniu łącznym.

${ }^{14}$ Ibidem, s. 145.

${ }^{15}$ Nawet jeśli sam Znamierowski zdaje się uważać rozkaz za paradygmat władzy, już jego opis różnych postaci stanowienia i ich rezultatu, którym jest norma (zespół norm), uzasadnia próbę obrony stanowiska uznającego za najbardziej wartościowe w kontekście problematyki władzy stanowienie łączne. Zob. ibidem, s. 174.

${ }^{16}$ Ibidem, s. 148.

17 Zob. ibidem, s. 161.

${ }^{18}$ Norma izolowana, tj. taka, przed której powstaniem jednostki nie obowiązywałaby żadna norma, a jej równowaga zapewniana byłaby przez inne czynniki niż stanowienie, a zarazem taka, którą jednostka stanowi sama dla siebie. Ustanowienie jej jest aktem faktycznym. Zob. C. Znamierowski, Prolegomena..., s. 29 i 85 . 
Oto przykład Znamierowskiego. Pewna indywidualna norma merytoryczna wyznaczyć ma osobie B obowiązek zerwania następnego ranka róży z krzewu przed domem. Zakłada się przy tym, że B nie chce stanowić o zerwaniu róży sam, lecz łącznie $\mathrm{z}$ inną osobą - A. Tym samym B wydziela czyn zerwania róży c(b) - z obszaru swego stanowienia i ustanawia na rzecz A normę kompetencji normodawczej co do owego czynu. Jeśli A przyjmie wezwanie do współpracy i uczyni z przyznanej kompetencji użytek, dochodzi do stanowienia łącznego.

Widać, że nie chodzi tu o jednoczesność działania, lecz o konieczne współ-

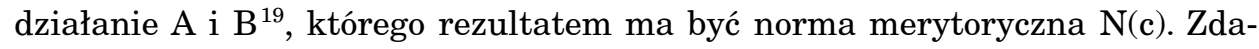
niem Znamierowskiego nie wystarczy jednak samo ustanowienie normy kompetencyjnej i norma merytoryczna jako rezultat uczynienia użytku z kompetencji, by uzyskać obraz norm, jakie wyłaniają się w tej sytuacji. Każdy z partnerów stanowiących łącznie nie powinien bowiem podejmować działań, które uniemożliwiłyby czyn c(b), gdyż ,,popadłby w sprzeczność z samym sobą" ${ }^{20}$ oraz zakwestionowałby stosunek, którego jest strona ${ }^{21}$. Prowadzi to do uznania, że wraz z ustanowieniem normy N(c) zaczynają obowiązywać ,normy generalnego zakazu" - określane odpowiednio dla A jako N(a) i dla B jako N(b) - zakazujące czynienia wszystkiego, co uniemożliwiłoby dokonanie $\mathrm{c}(\mathrm{b})$. Ustanowienie dla $\mathrm{B}$ normy nakazującej mu zerwanie następnego ranka róży z krzewu przed domem powoduje więc powstanie pewnego zespołu norm funkcjonalnie powiązanych. Według Znamierowskiego powstaje w ten sposób układ trzech norm niebędących normami indywidualnymi ${ }^{22}$. W stanowieniu łącznym nie jest zatem możliwe ustanowienie jednej normy merytorycznej, ponieważ zachodza pewne relacje instrumentalne między czynem przez tę normę wyznaczonym a innymi czynami podmiotów uczestniczących w jej ustanowieniu.

Analiza prostego przykładu stanowienia łącznego pokazuje jednak znacznie więcej z punktu widzenia pytania o władzę: pojawia się problem relacji między podmiotami oraz rodzaju powstajacych norm. Interesujace jest przy tym nie powstanie jakiejś normy merytorycznej, lecz norm generalnego zakazu, a zwłaszcza pytanie, dlaczego Znamierowski uważa, że nie są one normami indywidualnymi, to znaczy nie są to normy „,dla danej jednostki”, „dla imiennie określonego adresata" ${ }^{23}$.

Zaproponowane zostana trzy komplementarne interpretacje tego, czym sa owe normy generalnego zakazu jako normy nieindywidualne. Interpretacje te podkreślaja właściwości stanowienia łącznego oraz wyjaśniaja przydatność

19 Zob. ibidem, s. 143 i 146.

${ }^{20}$ Ibidem, s. 148.

${ }^{21}$ Zob. C. Znamierowski, Uktad prawny..., s. 69.

22 ,Jakkolwiek norma N(a) dotyczy tylko czynów naszego A, norma zaś N(b) tylko czynów B, niemniej normy te nie sa indywidualnemi normami naszego A, względnie naszego B. Obowiązują ze wspólnej racji, która jest obowiązywanie normy N(c), stworzone łącznem stanowieniem. Przeto te trzy normy stanowią jeden układ, wydzielony z układu norm prywatnych partnerów równowagi. B wydzielił z obszaru indywidualnego, czyny objęte normą N(b), wówczas, gdy stanowił normę kompetencyjną dla A co do czynu c(b). Czyny objęte normą N(a) wydzielił A ze swojego indywidualnego obszaru, gdy przyjął ofiarowaną mu kompetencję. Oczywista, obaj wydzielali te czyny rodzajowo, nie zaś indywidualnie; nie mając jeszcze normy o c(b), wiedzieć nie mogli, jakie czyny będą z nią kolidowały" (ibidem, s. 149).

${ }^{23}$ Ibidem, s. 138 i 139. 
kategorii stanowienia łącznego do zrozumienia władzy. Każda z propozycji interpretacyjnych zawiera odpowiedź na dwa pytania: 1) czy władza polegająca na stanowieniu norm jest w jakikolwiek sposób ograniczona?, 2) co czyni władzę legitymowaną, prawowitą? Interpretacje te hasłowo określić można jako: kooperacyjną, epistemiczną i systemową.

V. W interpretacji kooperacyjnej zdanie głoszące, że normy generalnego zakazu nie są normami indywidualnymi, można rozumieć jako głoszące, że realizacja wyznaczonych przez nie czynów któregokolwiek z podmiotów stanowienia łącznego przynajmniej w jakimś stopniu zależy od czynów drugiego podmiotu ${ }^{24}$.

Interpretacja kooperacyjna wychodzi od pytania, dlaczego Znamierowski uważa, że wskutek stanowienia łącznego powstają dwie normy generalnego zakazu. Zdaje się to naruszać zasadę ekonomii myślenia. Ponadto, w analizowanym przykładzie normy generalnego zakazu po prostu instrumentalnie wynikają z normy merytorycznej. Albo więc autor się myli, a normy generalnego zakazu są konsekwencjami zastosowania dyrektyw instrumentalnego zakazu i odnoszą się tylko do czynów tych osób, których dotyczy norma powstała w łącznym stanowieniu, albo normy generalnego zakazu odnoszą się także do powiązanych przyczynowo z czynem danej osoby czynów drugiej osoby. Jeśli przyjąc tę druga możliwość, to normy generalnego zakazu byłyby konsekwencjami zastosowania szczególnego rodzaju dyrektywy instrumentalnego zakazu, a mianowicie takiej, którą Ziembiński określał mianem „dyrektywy społecznego instrumentalnego zakazu" 25 .

Ten ostatni rodzaj krytyki zasługuje na uwzględnienie w zakresie, w jakim uzupełnia obraz powstawania norm generalnego zakazu, lecz nie podważa twierdzenia o wielości takich norm, a to ze względu na interpretację kooperacyjną. Można bowiem bronić stanowiska, że nie powstaje jedna norma generalnego zakazu, lecz właśnie - jak w analizowanym przykładzie - dwie. Zastosowanie dyrektywy instrumentalnego zakazu sensu stricto skutkuje bowiem następującym rozumowaniem: jeśli obowiązuje norma $\mathrm{N}(\mathrm{c})$, nakazująca B czynić C, to obowiązują też norma $\mathrm{N}(\mathrm{a})$, zakazująca osobie A (każdej nie-B) uniemożliwiania dokonania czynu $\mathrm{C}$ przez osobę $\mathrm{B}$, oraz norma $\mathrm{N}(\mathrm{b})$, zakazująca osobie B czynienia czegoś, co jej samej uniemożliwiłoby dokonanie czynu C. Utrzymywanie - jak w powyższym rozumowaniu - że powstają dwie normy generalnego zakazu, wydaje się sztuczne. Dopiero jeśli przyjać wersję instrumentalnego generalnego zakazu sensu largo, możliwe będzie wykazanie zarówno trafności poglądu, że w omawianym przykładzie stanowienia łącznego powstaja dwie normy generalnego zakazu, jak i sensowności kooperacyjnej interpretacji tych norm. Łatwo wykazać, że z normy generalnego zakazu

${ }^{24} \mathrm{~W}$ sensie technicznym są to oczywiście normy indywidualne, ze względu na sposób, w jaki charakteryzują adresatów. Sam Znamierowski nie przełamuje takiej konwencji w odniesieniu do norm indywidualnych. Tym ciekawsze jest podkreślanie przez niego, że normy $\mathrm{N}(\mathrm{a})$ oraz $\mathrm{N}(\mathrm{b})-$ normy generalnego zakazu - nie są normami indywidualnymi.

${ }^{25}$ Zob. Z. Ziembiński, Logiczne podstawy prawoznawstwa, Wydawnictwo Prawnicze, Warszawa 1966, s. 239. 
wynika norma nakazująca czynienie wszystkiego, co instrumentalnie konieczne do zrealizowania C. Jednak dopiero kooperacyjna interpretacja tego nakazu pozwala uzasadnić wyróżnianie dwóch norm: $\mathrm{N}(\mathrm{a})$ i $\mathrm{N}(\mathrm{b})$ jako norm konsekwencji obowiązywania $\mathrm{N}(\mathrm{c})$. Wskazanie dwóch takich norm (a nie jednej) ma bowiem sens tylko wtedy, gdy wyznaczają one swym adresatom obowiązi o tyle odmienne, że zależne nie tylko od własnych ich sytuacji, lecz także od sytuacji drugiego podmiotu. Wyróżnianie dwóch norm generalnego zakazu ma więc sens, o ile służy podkreśleniu konieczności współpracy obu partnerów stanowienia łącznego w celu realizacji normy merytorycznej.

Aby uzasadnić interpretację kooperacyjną można, po pierwsze, powołać się na stanowienie łączne jako genezę norm generalnego zakazu. Byłyby zatem $\mathrm{w}$ interpretacji kooperacyjnej normy generalnego zakazu normami nieindywidualnymi, gdyby to, co „indywidualne”, oznaczało „,samowystarczalne”, „niewymagające współdziałania”, ponieważ stanowią konsekwencję współdziałania przy ich ustanowieniu. Znamierowski przyjmuje, że każdy z uczestników stanowienia zgodził się wydzielić $\mathrm{z}$ obszaru indywidualnego czyny objęte odpowiednimi normami generalnego zakazu, $\mathrm{w}$ dodatku nie wiedząc, jakie to będa czyny, skoro miało to miejsce przed ustanowieniem normy merytorycznej. Użycie czasownika ,,wydzielić” w odniesieniu do aktów każdego z podmiotów może wskazywać na ekwiwalencję $\mathrm{w}$ działaniach delimitujących zakres przyszłych czynów adresata normy. Każdy z nich ogranicza ów zakres o te czyny, które wskutek dokonania odpowiednich czynności - ustanowienia normy kompetencji normodawczej i uczynienia użytku z tej normy - przechodzą do zakresu czynów wymagających biernego lub czynnego współdziałania drugiego podmiotu. W konsekwencji czyny wyznaczone przez normy generalnego zakazu przestają być indywidualne, gdyż są rezultatem stanowienia łącznego: ku sprawom drugiej osoby nakierowane są działania, polegające odpowiednio na czynieniu użytku z kompetencji oraz na realizowaniu normy merytorycznej w tym sensie, że wpływaja na sytuację drugiego podmiotu.

Ponadto stanowienie łączne wymusza kooperację i koordynację działań. Ustanowienie normy kompetencji normodawczej i jej przyjęcie prowadzą do powstania stosunku, w którym ważne jest nie tyle podleganie przez B kompetencji, w jaką wyposażył normodawcę A, ile raczej obowiązek współdziałania wygenerowany przez wspólne stanowienie. To myśl bardzo nowoczesna, odległa od typowego ujmowania stanowienia jako czynności, przez która podmiot wyposażony w kompetencję normodawczą ,żąda posłuchu” dla stanowionych przez siebie norm.

Stanowienie łączne jako współdziałanie zawierałoby więc - w interpretacji kooperacyjnej - ograniczenie władzy polegające, po pierwsze, na obowiązku współdziałania: zarówno ze względu na przyjęcie kompetencji normodawczej, jak i na konsekwencje uczynienia użytku z kompetencji i ustanowienia normy $\mathrm{N}(\mathrm{c})$. Wyrazem współdziałania jest zmniejszenie ryzyka stanowienia norm obarczonych wadami ${ }^{26}$. Po drugie, realizacja wyznaczonych przez normy

${ }^{26}$ Dlatego, że ,,[o]dwołując się do opinji i woli A, nasz B wykazuje tem, że nie chce zawierzyć decyzji własnej wyłącznie i że chce ją skorygować przez udział drugiej osoby w stanowieniu. [...] Ten korygujący i hamujący wpływ drugiego współuczestnika w stanowieniu zaznacza się jeszcze wyraźniej, gdy chodzi o normę powszechną" (C. Znamierowski, Prolegomena..., s. 155). 
generalnego zakazu czynów któregokolwiek z podmiotów stanowienia łącznego $\mathrm{w}$ jakimś stopniu zależy od czynów drugiego podmiotu. Konsekwencje stanowienia łącznego można zarazem traktować jako strukturalne ograniczenie władzy stanowienia. Rezultatem stanowienia jest norma ,międzyosobowa” N(c) ${ }^{27}$ o postaci: B powinien $\mathrm{c}$ w warunkach w. Zarówno normodawca, jak i adresat normy maja - według Znamierowskiego - swoje układy norm autonomicznych U(A) i U(B), między którymi pojawia się norma N(c). W efekcie sytuacja normodawcy także ulega przekształceniu, wynikającemu z tego, co Znamierowski określa jako obowiązek konsekwencji, polegający na tym, by „po pierwsze, aprobować czyn nakazany; po drugie zaś [A - przyp. M.D.] winien sam zachowywać się w ten sposób, iżby działaniem swem nie stwarzać rozmyślnie i świadomie takiej sytuacji działania dla B, w której czyn c, wyznaczony przez normę $M$ [w tych rozważaniach określanej jako norma N(c) - przyp. M.D.], stałby się niemożliwy w wypadku spełnienia się warunków, przez normę wskazanych" ${ }^{28}$. Normy N(c), N(a) i N(b) tworzyć maja nierozdzielny układ międzyosobowy. Biorąc pod uwagę rozumienie obowiązywania jako stanu równowagi między sytuacjami partnerów, sens twierdzenia o związaniu normodawcy norma $\mathrm{N}(\mathrm{c})$ wykracza poza proste uznanie, że norma ustanowiona obowiązuje ustanawiającego. Zmienia się bowiem w wyniku ustanowienia normy $\mathrm{N}(\mathrm{c})$, poprzez normę $\mathrm{N}(\mathrm{a})$, układ norm $\mathrm{U}(\mathrm{A})$, który musi uwzględnić tę zmianę - na przykład poprzez wyeliminowanie norm niezgodnych z N(c) - a tym samym ów zaktualizowany układ wyznacza granice międzyosobowej kompetencji normodawczej A.

VI. W interpretacji epistemicznej zdanie głoszące, że normy generalnego zakazu nie są normami indywidualnymi, można rozumieć jako głoszące, że czyny wyznaczone przez te normy są treściowo niedookreślone. Może to wynikać $\mathrm{z}$ braku wiedzy o treści normy merytorycznej zarówno po stronie tego, kto ustanawia kompetencję normodawczą, jak i tego, kto czyni z niej użytek. Normy generalnego zakazu są konsekwencją ustanowienia kompetencji i jej przyjęcia, ale co ma zostać zakazane, okaże się dopiero, gdy powstanie norma merytoryczna. Wiadomo, że jakieś czyny będą normami N(a) i N(b) zakazane, lecz niekoniecznie wiadomo, jakie będą to czyny; nie są one dostatecznie zindywidualizowane.

Dla charakterystyki stosunku władzy nie jest ważne, czy rezultatem procesu stanowienia łącznego jest norma merytoryczna indywidualna czy generalna. Dlatego podkreślanie przez Znamierowskiego różnicy w symetrii między sytuacjami współpartnerów nie wydaje się dobrze uzasadnione ${ }^{29}$. W tym właśnie przejawia się ów epistemiczny aspekt norm generalnego zakazu, że partnerzy współstanowienia nie wiedzą, jakie zachowania wyznaczy im ustanowiona norma lub jej normy konsekwencje. Taki opis stanowienia łącznego da się

27 Tzn. ustanowiona przez A dla B.

${ }^{28}$ C. Znamierowski, Prolegomena..., s. 171.

${ }^{29}$ Sam zresztą przyznaje: „Zarówno A jak B, nie wiedząc, czy nie na niego przypadnie obowiązek wykonania czynu c, winien uczynić zgodnie ze swą wiedzą o związkach przyczynowych wszystko, aby móc wykonać czyn powinny. Pod tym względem zresztą [...] norma indywidualna też traktowała na równi obu partnerów, stwarzając współtowarzyszące jej normy zakazu”; ibidem, s. 153. 
zastosować do każdego rodzaju stanowienia, skoro zanim norma zostanie ustanowiona, nie jest znana jej treść. Jednak niewiedza w stanowieniu łącznym podkreśla raczej własności władzy niż stanowienia. Współdziałanie, będące charakterystyczną cechą stanowienia łącznego, ma po prostu także swój wymiar epistemiczny.

W wypadku stanowienia łącznego niewiedza zrównuje pozycje podmiotów. Choć wydaje się, że podmiot wyposażony w kompetencję normodawczą pozna normę merytoryczną wcześniej niż ten, który go w tę kompetencję wyposażył, uprzednia wiedza podmiotu podległego kompetencji normodawczej o treści ustanawianej normy mogłaby być większa niż wiedza partnera upoważnionego. Samo bowiem sformułowanie normy merytorycznej może być w tak wysokim stopniu zdeterminowane warunkami, w jakich ustanawiano normę kompetencyjną, że w dużej mierze przesądzać będzie o jej treści, a zatem podmiot podległy kompetencji również wcześniej będzie dysponował wiedzą o treści normy. Nie można także wykluczyć sytuacji, w której podmiot wyposażony w kompetencję normodawczą poznałby treść normy nie wcześniej niż podmiot podległy kompetencji normodawczej. Skoro zaś normy generalnego zakazu zależą treściowo od normy merytorycznej, w ich powstanie wpisane sa te same problemy epistemiczne.

Problem wiedzy w stanowieniu jest jednak bardziej skomplikowany, gdyż nie dotyczy tylko treści normy, która jest rezultatem stanowienia łącznego. W związku ze stanowieniem odróżnić trzeba wiedzę o faktach i związkach przyczynowych od wiedzy o ocenach. Obie odgrywają ważną rolę zarówno w samym procesie stanowienia, jak i we wnioskowaniach o wynikaniu norm $\mathrm{z}$ norm.

Ograniczenie władzy stanowienia jest wpisane $\mathrm{w}$ interpretacje epistemiczną, ponieważ interpretacja ta pokazuje, jak rozproszona jest wiedza (i niewiedza) u podstaw normowania. Pozwala to ujać stanowienie łączne jako procedurę poznawczą, w której partnerzy stanowienia dzielą wiedzę i niewiedzę, a zatem - o ile procedura ta ma być skuteczna - żaden z nich nie może rościć sobie tytułu do monopolu na wiedzę.

Legitymizacja władzy jako łącznego stanowienia norm polega w tej interpretacji na wykazaniu, że to nie normodawca posiada odpowiednią wiedzę, by stanowić normy, lecz że ze względu na charakter towarzyszących stanowieniu łącznemu procesów poznawczych, autorytet epistemiczny przysługuje normom, będącym rezultatem takiego stanowienia ${ }^{30}$. Autorytetem epistemicznym jest więc właściwość rezultatów stanowienia, a to z powodu kumulacji wiedzy, która legła u podstaw ustanowienia normy merytorycznej oraz norm konsekwencji.

VII. W interpretacji systemowej zdanie głoszące, że normy generalnego zakazu nie są normami indywidualnymi, można rozumieć jako zdanie, które głosi, że wraz z normą, której są konsekwencjami, stanowią one zalążek systemu norm.

\footnotetext{
${ }^{30}$ By przewrotnie użyć określenia J. M. Bocheńskiego, który odróżnia autorytet epistemiczny $\mathrm{w}$ dziedzinie zdań od autorytetu deontycznego w dziedzinie dyrektyw, w: idem, Co to jest autorytet?, w: Logika i filozofia, PWN, Warszawa 1993, s. 231 i n.
} 
Systemowość ta ma dwa aspekty: dany (statyczny) oraz potencjalny (dynamiczny). Pierwszy pozwala stwierdzić, że już w wyniku uczynienia użytku z kompetencji normodawczej przez partnerów stanowienia łącznego powstaje mikrosystem norm. Jedna norma nie tworzyłaby systemu, stąd tak wielkie znaczenie norm generalnego zakazu. Normy N(c), N(a) i N(b) tworzyć maja, jak wspomniano, nierozdzielny układ międzyosobowy ${ }^{31}$. Zmieniaja się bowiem w wyniku ustanowienia normy $\mathrm{N}(\mathrm{c})$, poprzez normę $\mathrm{N}(\mathrm{a})$, autonomiczne układy norm U(A) i U(B), ponieważ muszą uwzględnić tę zmianę - na przykład poprzez wyeliminowanie norm niezgodnych z N(c). Tym samym możliwe jest wyłączenie norm ze zaktualizowanych układów norm i włączenie ich do nowego układu międzyosobowego U(c), mającego cechy systemu norm: stanowią one całość w pewien sposób uporządkowaną, w szczególności poprzez więź statyczną. Normą naczelną będzie dla rozpatrywanego mikrosystemu norma N(c) oraz jej normy konsekwencje - N(a) i N(b), a także inne, jeśli przyjąć sensowność kooperacyjnej interpretacji norm generalnego zakazu.

Drugi, dynamiczny aspekt systemowości układu norm powstających w stanowieniu łącznym polega na ich więzi opartej na normie kompetencji normodawczej. Źródłem stanowienia łącznego jest ustanowienie normy kompetencji normodawczej przez jeden podmiot na rzecz drugiego, z którym ,,chce rozstrzygnąć [...] sprawę łącznie" ${ }^{32}$. Dopiero stanowienie łączne wyjaśnia kompetencje jako warunek konieczny stanowienia, ponieważ ustanowienie normy w drodze rozkazywania może (choć nie musi) opierać się na możności faktycznej.

Systemowa interpretacja norm generalnego zakazu rzuca światło na normę kompetencji normodawczej, pokazując, że stanowienie łączne ma sens społeczny, a więź kompetencyjna nie jest wyłącznie formalna. Chęć łącznego rozstrzygnięcia jakiejś sprawy nie polega bowiem na ustanowieniu normy kompetencji normodawczej do ustanowienia normy o treści z góry ściśle określonej. Interpretację systemowa uzupełnia tu interpretacja epistemiczna.

Systemowość stanowienia łącznego jest nie tylko dana w jego normatywnych rezultatach, lecz jest także potencjalna jako możliwość rozwijania się systemu norm. Konsekwencją obowiązywania norm generalnego zakazu może być konieczność takiego rodzaju współdziałania, by ustanowić dalsze normy kompetencji normodawczej, na przykład w celu doprecyzowania treści obowiązków współpracy. Dalszy rozwój systemu norm może także dokonywać się, gdy norma $\mathrm{N}(\mathrm{c})$ będzie normą kompetencyjna. Wprawdzie dotychczas dla uproszczenia rozważań przyjmowano, że ustanowiona łącznie norma N(c) jest merytoryczna w rozumieniu współczesnego prawoznawstwa, ale dla Znamierowskiego norma kompetencyjna jest szczególnego rodzaju normą merytoryczną, ponieważ przyjmuje on, że jeśli norma wyznacza działanie polegające na stanowieniu, to jest międzyosobową normą kompetencyjną ${ }^{33}$.

${ }^{31}$ Zob. C. Znamierowski, Prolegomena..., s. 170.

${ }^{32}$ Ibidem, s. 145.

${ }^{33}$ Ibidem, s. 175. Oczywiście także w przypadku takiej normy możliwe jest stanowienie łączne: gdy B oddaje ustanowienie normy kompetencji normodawczej łącznemu stanowieniu swojemu wraz z A. Normy generalnego zakazu odnosiłyby się mutatis mutandis do czynienia użytku z kompetencji normodawczej przez podmiot upoważniony. 
Odpowiedzi na pytanie o ograniczanie władzy stanowienia w interpretacji systemowej można udzielić osobno w odniesieniu do więzi statycznej i do więzi dynamicznej w systemie norm, adaptując wprowadzone przez Znamierowskiego rozróżnienie władzy aktualistycznej i posybilistycznej ${ }^{34}$.

Norma będąca rezultatem stanowienia łącznego, rozważana jako naczelna z perspektywy więzi statycznej systemu norm, ogranicza władzę w znaczeniu aktualistycznym. Norma N(c) wraz z jej normami konsekwencjami N(a) i N(b) tworzyć mają nierozdzielny układ międzyosobowy. Biorąc pod uwagę charakterystyczne dla Znamierowskiego rozumienie obowiazywania jako stanu równowagi między sytuacjami (,układami norm”) partnerów, sens twierdzenia o związaniu normodawcy normą $\mathrm{N}(\mathrm{c})$ wykracza poza proste uznanie, że norma ustanowiona obowiązuje ustanawiającego. Zmienia się bowiem $\mathrm{w}$ wyniku ustanowienia normy $\mathrm{N}(\mathrm{c})$, poprzez normę $\mathrm{N}(\mathrm{a})$, układ norm $\mathrm{U}(\mathrm{A})$, który musi uwzględnić tę zmianę - na przykład poprzez wyeliminowanie norm niezgodnych z N(c), a tym samym zaktualizowany układ wyznacza granice międzyosobowej kompetencji normodawczej A. Norma N(c) może także, poprzez normę N(b), wpływać na ewentualne dalsze ustanawianie norm kompetencji normodawczej przez B na rzecz A.

Z kolei pierwsza norma kompetencji normodawczej ustanawiana przez B dla jego łącznego stanowienia z A o czynie $\mathrm{C}$ ogranicza władzę w znaczeniu posybilistycznym. Znamierowski nie odróżnia wprawdzie normy kompetencyjnej od związanego z nią nakazu albo zakazu uczynienia użytku z kompetencji, dostrzega jednak w owym funkcjonalnie $\mathrm{z}$ kompetencja powiązanym nakazie bądź zakazie możliwe ograniczenie władzy normodawczej.

Wydaje się, że sama systemowość norm powstałych w stanowieniu łącznym ma nikły potencjał legitymizacyjny. System norm stabilizuje się przez normę naczelną, lecz może to być norma o jakiejkolwiek treści. Ustanowienie normy kompetencji normodawczej określa źródło norm, zapewniając konieczny i strukturalny warunek prawowitości władzy jako stanowienia. Strukturalny, ponieważ bez ustanowienia tej normy w ogóle o stanowieniu łącznym nie można by mówić.

Lepiej legitymizuje normodawcę system norm aprobowanych niż takich, którym aprobatę trudno uzyskać, choć z punktu widzenia systemowości jako cechy formalnej (porządkowalności) taka aprobata jest co najwyżej wartością dodana. Można jednak ostrożnie bronić systemowości jako wyniku stanowienia łącznego, z zastrzeżeniem, że ta właściwość norm jako rezultat stanowienia innego typu w mniejszym stopniu zasługiwałaby na taką obronę.

Spośród różnych typów stanowienia norm tylko stanowienie łączne wyjaśnia pochodzenie normy kompetencji normodawczej, bez której nie powstanie więź dynamiczna systemu norm. Wyjaśnienia takiego nie dostarcza rozkazywanie: norma merytoryczna może powstać poprzez faktyczną możność rozkazywania, a zatem bez uprzedniego ustanowienia normy kompetencji normodawczej. $\mathrm{Z}$ tego samego powodu tylko stanowienie łączne dostarcza legitymizacji

\footnotetext{
${ }^{34}$ Chodzi o rozróżnienie na władzę w znaczeniu aktualistycznym (A ma władzę nad B, gdy jego rozkaz spotkał się z posłuchem) oraz w znaczeniu posybilistycznym (A ma władzę nad B, gdy zachodzi prawdopodobieństwo, że jego rozkaz spotka się z posłuchem). Por. C. Znamierowski, Prolegomena..., s. 113. Adaptacja polega tu na przyjęciu perspektywy systemu norm zamiast perspektywy działań albo dyspozycji odbiorcy rozkazu.
} 
kompetencji normodawczej, ponieważ nie wystarczy tu akt woli tego, kto normę tę ustanawia, ale potrzebne jest przyjęcie tego upoważnienia.

Szczególne zalety stanowienia łącznego ujawniają się także w odniesieniu do ustanowienia normy merytorycznej, która w rozważanym mikrosystemie norm będzie zarazem naczelna. Zalety te zostały podniesione $\mathrm{w}$ kooperacyjnej i epistemicznej interpretacji norm generalnego zakazu i daja się odnieść do normy, z której normy generalnego zakazu zostają wyinferowane.

VIII. Władza ujęta jako łączne stanowienie norm jest więc takim stosunkiem między A a B, że gdy B dokona czynności ustanowienia normy kompetencji normodawczej $\mathrm{N}(\mathrm{k})$ na rzecz A oraz zarazem A uczyni użytek $\mathrm{z}$ kompetencji normodawczej, wówczas A łącznie z B ustanowią zespół norm $\mathrm{S}$ (obejmujący co najmniej normy $\mathrm{N}(\mathrm{c})$ oraz $\mathrm{N}(\mathrm{a})$ i $\mathrm{N}(\mathrm{b})$ ).

Takie ujęcie władzy nie rości sobie pretensji do uniwersalności i zostało zaproponowane z myślą o władzy publicznej jako sformalizowanej władzy grupy społecznej, realizującej określone zadania i cele. Ponadto, skoro od początku rozważań przyjmowano, że władza polega na stanowieniu norm, rozważania te oraz wnioski odnoszą się w dużej mierze do stanowienia, rozjaśniając ignotum tetycznego obowiązywania normy, ponieważ: po pierwsze, stanowienie łączne podważa ujęcie stanowienia jako wyłącznie czynności jednostronnej; po drugie, wyjaśnia źródło konwencjonalności stanowienia; po trzecie, wprowadza do stanowienia uprawomocnienie; po czwarte, eliminuje z definicji stanowienia element represji.

Zaproponowane rozumienie władzy wyjaśnia, dlaczego jest ona stosunkiem dwustronnym. Ujęcia stanowienia jako czynienia użytku z kompetencji normodawczej przedstawia połowiczny obraz stanowienia. Być może doniosła poznawczo refleksja nad stanowieniem powinna ograniczyć się do działań podmiotu ustanawiającego normę kompetencji normodawczej. Wówczas z zakresu tej refleksji wyłączone zostaną rezultaty stanowienia, co istotnie utrudni lub uniemożliwi ujmowanie władzy jako stosunku polegającego na stanowieniu norm. Wydaje się, że źródło nieporozumień związanych z ujmowaniem stanowienia jako jednostronnej czynności konwencjonalnej tkwi w nierozróżnianiu społecznego stosunku stanowienia od aktu stanowienia, władzy od aktu władczego.

Stanowienie łączne wyjaśnia źródło konwencjonalności stanowienia norm, wprowadzając pojęcie kompetencji jako konieczny warunek rozważań o stanowieniu, dlatego odwołując się do ,warunków tetycznych” ${ }^{35}$, stanowienie łączne lepiej opisuje władzę w grupach złożonych. Konwencjonalność stanowienia przejawia się w umowności aktów składających się na stanowienie łączne (nie w sensie kontraktualistycznym, ponieważ umowność odnosi się do samych działań partnerów stanowienia łącznego, a nie do faktu normotwórczego). Istotą stanowienia łącznego nie jest bowiem umowa, lecz - jak powiada Znamierowski - „,sztuczna synteza” działań partnerów, która w ogóle stanowić ma istotę władania ${ }^{36}$.

35 C. Znamierowski, Uktad prawny..., s. 81.

${ }^{36}$ Zob. C. Znamierowski, Prolegomena..., s. 182. 
Ignotum tetycznego uzasadnienia obowiązywania normy kryje się głównie $\mathrm{w}$ słabszym $\mathrm{w}$ porównaniu z uzasadnieniami aksjologicznym i behawioralnym czynniku uprawomocnienia. Tymczasem stanowienie łączne, dzięki zaproponowanym tu interpretacjom kooperacyjnej, epistemicznej i systemowej, niedostatki te umniejsza. Wskazuje bowiem na wymóg współpracy i uczestnictwa w stanowieniu, które legitymizują je lepiej niż akt uznania przez podmiot podległy kompetencji normodawczej. Większe jest też prawdopodobieństwo aprobaty dla rezultatów stanowienia. W stanowieniu łącznym gromadzona jest rozproszona wiedza partnerów, co z kolei podkreśla jego dialogiczny charakter. W stanowieniu łącznym uwidacznia się wreszcie kreowanie podstaw więzi statycznej i dynamicznej norm należących do systemu. Można by rzec, w nawiązaniu do stanowiska Josepha Raza, iż generując autorytet jako źródło normatywnych racji dla działania, stanowienie łączne w większym stopniu niż rozkaz umożliwia wyjaśnienie, dlaczego racje te zostaja przyjęte. Tym samym wspomniany na początku dylemat autorytetu praktycznego może zostać wyjaśniony. Co do jego pierwszego członu, w stanowieniu łącznym adresat nie traci swoich racji do działania, o ile je posiadał. Może natomiast zyskać nowe racje lub zmianę kwalifikacji własnych racji. W odniesieniu do drugiego członu dylematu Marmora koncepcja stanowienia łącznego oferuje wyjaśnienie, polegające na odwołaniu się do aktów woli uczestników stanowienia łącznego podmiotu chcącego stanowić łącznie i ustanawiającego w tym celu normę kompetencji normodawczej oraz podmiotu przyjmującego ofiarowana kompetencję.

Wreszcie w wypadku stanowienia łącznego wyjaśnienie stosunku władzy paradoksalnie nie musi być bardziej złożone niż w wypadku rozkazywania, ponieważ nie zachodzi potrzeba włączania do charakterystyki stanowienia sytuacji przymusowej. Nie chodzi zresztą w tym miejscu o krytykę rozkazu, co w pohartowskiej teorii prawa byłoby truizmem, lecz o wykazanie przydatności koncepcji stanowienia łącznego w refleksji teoretycznoprawnej. Władza jako stosunek oparty na stanowieniu łącznym nie jest bowiem w najmniejszym stopniu funkcja działań ani dyspozycji odbiorcy rozkazu, co wyłącza represję jako warunek konieczny zaistnienia i trwania stosunku władzy.

IX. Czy taka koncepcja stanowienia łącznego, z wszystkimi jej teoretycznymi zaletami w stosunku do stanowienia jako jednostronnej czynności upoważnionego podmiotu, jest przydatna w prawniczych rozważaniach o władzy publicznej?

Analizy władzy w nauce prawa publicznego i teorii prawa moga skorzystać z pełnego obrazu stosunku, zwłaszcza od strony typów norm, jakie się nań składają. Koncepcja taka koresponduje też z demokratycznymi i egalitarystycznymi ideologiami władzy publicznej. Trudność może natomiast wiązać się $\mathrm{z}$ charakteryzowaniem relacji podmiotów władzy jako stosunku polegającego na łącznym stanowieniu norm oraz z przypisywalnością działań, składających się na stanowienie. Tej trudności nie usuwa jednak również koncepcja stanowienia jako rozkazywania lub jednostronnego działania opartego na kompetencji.

Nawet proste podstawienia pod modelową postać stanowienia łącznego ujawniają pewne właściwości władzy publicznej, które odpowiadają powszechnym intuicjom, zrodzonym na gruncie obowiązywania Konstytucji RP. Można 
na przykład uznać, że jeżeli suweren ustanowi normę kompetencji normodawczej dla ustawodawcy (zarazem ustrojodawcy), a ten przyjmie upoważnienie (przez uczynienie użytku z kompetencji), to łącznie ustanowią pewien zespół norm. Ten rodzaj stanowienia łącznego jest genezą władzy publicznej, jako opartej na prawie, i zarazem daje początek dalszym stanowieniom łącznym, w których organy władzy publicznej będą partnerami dla innych organów lub dla obywateli. Natomiast wątpliwa wydaje się trafność twierdzenia, że suweren dokonuje stanowienia łącznego norm z władzą wykonawczą czy z władzą sądowniczą, które to władze ustrojodawca kreuje, wyposażając w pewne „minimum wyłączności kompetencyjnej”. W ten sposób powstają ramy tego, co określa się jako działanie lub funkcjonowanie władzy, polegające między innymi na łącznym stanowieniu norm, zarówno generalnych i abstrakcyjnych, jak i indywidualnych i konkretnych.

Oczywiście inaczej wygląda teoretycznoprawna charakterystyka genezy władzy (np. w sytuacji pierwotnej czy w anomii), a inaczej - rozwiniętego systemu prawnego. Pełna charakterystyka według modelu stanowienia łącznego, w której dochodzi do ustanowienia normy kompetencji normodawczej, jest łatwiejsza w sytuacjach pierwszego typu, w których stosunek władzy może być rozpatrywany jako społeczny stosunek faktyczny. Nie oznacza to jednak, że zasadnicze elementy stanowienia łącznego nie nadają się mutatis mutandis do charakterystyki stosunków tetycznych.

Można podejmować taką charakterystykę poprzez odwoływanie się do źródła kompetencji normodawczej w wypadku danego stosunku władzy, ale można także wskazywać na pewne typowe elementy stanowienia łącznego występujące $\mathrm{w}$ analizowanych stosunkach. Władza analizowana w demokratycznych systemach prawnych okaże się wówczas o wiele bardziej rozproszona, niż zwykliśmy sądzić, a stanowienie łączne lepiej niż stanowienie jednostronne zda sprawę $\mathrm{z}$ tego rozproszenia. Wbrew pozorom podmiot władzy publicznej całkiem często znajduje się w sytuacji, w której - jak mówi Znamierowski - ,,chce rozstrzygnąć sprawę łącznie”. Stosunki władzy, których rezultatem są normy, rzadko polegają na działaniu sua sponte, a pojawiajace się $\mathrm{w}$ nich elementy stanowienia łącznego wiążą się przede wszystkim z występowaniem rozmaitych „,mechanizmów aktywacyjnych", a dalej z normatywnymi konsekwencjami, obejmującymi sytuacje prawne partnerów stanowienia łącznego.

W tym kontekście nie tylko władza prawodawcza, lecz także władza wykonawcza oraz władza sądownicza, w pewnym zakresie, moga zostać trafnie przedstawione za pomoca koncepcji stanowienia łącznego. Stanowienie łączne nie ma jednak wyjaśniać aktów władzy, a raczej samą władzę. Gdyby władza wykonawcza ograniczała się jedynie do wykonywania ustaw pochodzących od władzy ustawodawczej, nie byłaby władzą. Wydaje się zatem, że tam, gdzie władza publiczna działa wspólnie z podmiotami prywatnymi, dobrym ujęciem władzy będzie właśnie stanowienie łączne. Szczegółowe analizy pozostaja jednak poza przedmiotem niniejszych rozważań, które moga stanowić dla nich punkt wyjścia. 


\section{CZESŁAW ZNAMIEROWSKI'S CONCEPTION OF POWER AS A JOINT ENACTMENT OF NORMS}

\section{Summary}

This paper aims to explain the relationship between power and the creation of norms, based on the conception of a joint enactment of norms developed by Czesław Znamierowski. The joint enactment is supposed to result in non-individual norms of general prohibition. Three interpretations of such norms have been developed in order to shed light on some power-related issues. It is further claimed that political and legal power can be explained in terms of a joint enactment of norms. 
Copyright of Journal of Law, Economics and Sociology is the property of Faculty of Law and Administration of Adam Mickiewicz University in Poznan and its content may not be copied or emailed to multiple sites or posted to a listserv without the copyright holder's express written permission. However, users may print, download, or email articles for individual use.

Właścicielem praw autorskich do „Ruchu Prawniczego, Ekonomicznego i Socjologicznego” jest Wydział Prawa i Administracji Uniwersytetu im. Adama Mickiewicza w Poznaniu. Zawartość czasopisma nie może być kopiowana, przesyłana do innych stron internetowych bądź zamieszczana na blogach bez pisemnej zgody wydawcy. Niemniej artykuły można drukować, kopiować lub przesyłać w formie elektronicznej na własny użytek. 